\title{
Byzantine Romanness: From geopolitical to ethnic conceptions
}

\author{
Ioannis Stouraitis
}

In a paper focusing on the issue of personal identity, the philosopher Derek Parfit summarized the distinction between the concepts of numerical and qualitative identity as follows:

\begin{abstract}
Two white billiard balls may be qualitatively identical, or exactly similar. But they are not numerically identical, or one and the same ball. If I paint one of these balls red, it will cease to be qualitatively identical with itself as it was; but it will still be one and the same ball. Consider next a claim like, "Since her accident, she is no longer the same person". That involves both senses of identity. It means that she, one and the same person, is not now the same person. That is not a contradiction. The claim is only that this person's character has changed. This numerically identical person is now qualitatively different. ${ }^{1}$
\end{abstract}

These two conceptual approaches to sameness seem to me to provide an appropriate point of departure for an introduction to the issue of Romanness in early medieval Byzantium. The loss of the Late Roman Empire's western parts in the fifth century and the extensive territorial contraction of Justinian I's restored empire, along with the linguistic Hellenization of the Roman imperial administration, between the late-sixth and late-seventh centuries, meant that the numerically identical political entity Roman Empire, the realm demarcated by the boundaries of enforceable authority of the Roman imperial office, was not the same any more, i.e. became qualitatively different. This difference is conceptualized in modern-day scholarly discourse by the terminus technicus: the Byzantine Empire.

In the light of the unbroken continuity of the political overstructure in the medieval East Roman Empire, posing the question about the transformation of Romanness there means that, as opposed to post-Roman Western Europe, one is not looking for the survival of shifting notions of Romanness within a framework of construction of new polities and ethnic identities, ${ }^{2}$ but rather for the qualitative change of the Roman imperial polity and its collective identity discourse. In the comparative context of the current volume, my paper will therefore focus on the question as to the development of the form and content of Byzantine Romanness in an early medieval world (c. 500-1000), where the territorial contraction of centralized Roman imperial rule and the subsequent political fragmentation of the larger part of the orbis romanus had made ethnic discourse politically important again.

\footnotetext{
${ }^{1}$ Parfit 1995, 13-14.

${ }^{2}$ Cf. Heather 2005, 432-443.
} 


\section{A short conceptual excursus}

Within the framework of a revived sociological debate over the concepts of ethnie and nation, which incrementally intensified in the last three decades, ${ }^{3}$ the scrutiny of the form and content of Byzantine Romanness, as a medieval political entity's collective identity, inevitably needs to take into consideration problems of conceptualization.

The current debate on collective identity is marked by revisionist approaches to the dominant modernist paradigm that defines nations and nation-states as a phenomenon resulting from the watershed of modernity and post-dating the eighteenth century. The more sophisticated modifying arguments of the modernist thesis have come from the so-called ethno-symbolist approach that revisited the role of ethnic ties in the pre-modern world and pleaded for an important contribution of pre-modern ethnic traditions to the configuration of modern national identities. The elaborate version of this approach sees the concept of the nation as predating modernity and suggests that, when certain ideal preconditions are met, politically organized pre-modern ethnic groups could be regarded as national communities. ${ }^{4}$

If the central argument of ethno-symbolism mainly refers to a neoperennialist perspective regarding the ethnic cores of modern nations, a recent argument by the political scientist Azar Gat advocated a radical revisionism regarding the modernity of the phenomena nationhood and nation-state. Based on a paraphrasis of Ernest Gellner's definition of the nation as 'a rough congruence between culture or ethnicity and state', Gat asserted that we should rather acknowledge the existence of "nations and national states wherever states emerged since the beginning of history'. 5

The pros and cons of both aforementioned theoretical approaches cannot be dealt with analytically here due to lack of space. Drawing attention to them, however, is important for the Byzantine case, since their rationale seems to correspond, at least in part, with two distinct approaches to Romanness in post-seventh century Byzantium. The distinguished Byzantinist Speros Vryonis, who provided detailed arguments in the past in favour of an essentialist approach to the role of Greek culture in Eastern Roman identity discourse rendering Byzantine Romanness as a bearer of perennial Greek ethnicity, ${ }^{6}$ has recently argued that Anthony D. Smith's ethno-symbolist revision of the modernist paradigm should be celebrated as the new theoretical orthodoxy. ${ }^{7}$ On the other hand, Azar Gat might have included the case

\footnotetext{
${ }^{3}$ For good overviews of the main positions in this ongoing debate see Ichijo/Uzelac 2005; A. Smith 2009; Malešević 2013.

${ }^{4}$ A. Smith 2004b, 18-20; A. Smith 2005, 104-107; A. Smith 2009, 23-59.

${ }^{5}$ Gat 2013, 2-4.

${ }^{6}$ See Vryonis 1978; Vryonis 1999.

${ }^{7}$ Vryonis 2011.
} 
of the East Roman Empire as a historical example in favour of his thesis, ${ }^{8}$ had he been aware of the work of another prolific scholar of Byzantine history, Anthony Kaldellis. The latter has recently argued that post-seventh-century Byzantium was a pre-modern nation-state and Byzantine Romanness a national identity. ${ }^{9}$

In light of these differentiated approaches, I think it is necessary to briefly clarify what I understand under the rubrics ethnie and nation before embarking on an interpretative presentation of source material regarding the form and content of Roman identity in early medieval Byzantium (c. $6^{\text {th }}-10^{\text {th }}$ c.). In my view, the aforementioned theoretical developments pose two questions: first, whether ethnicity and nationhood should be conflated or could be seen as overlapping concepts in a medieval context. Second, whether it is analytically fruitful for historical research to loosen the concepts of the empirically studied modern phenomena nation and nation-state to the extent that these can be applied to whole pre-modern empires, as for instance China and Rome (or, for that matter, the early medieval East Roman Empire). ${ }^{10}$

Beginning with the first issue, social anthropology long ago dismissed the primordial character of ethnicity by pointing out that the latter does not consist in the possession of cultural characteristics by the members of a group, but in the recognition of their cultural difference by others through social interaction. ${ }^{11}$ Ethnic, therefore, is how a collectivity is conceived and represented, not the way it comes into being. The crucial point here is that ethnicity refers to processes of negotiated cultural classification depending extensively on practices of external categorization that make chosen cultural markers of the 'other' salient and thus socially meaningful. ${ }^{12}$ Ethnic categorization - as an omnipresent phenomenon in medieval sources - is closely connected with various objective cultural markers (language, religion, pigmentation etc.) that outsiders chose to highlight in order to categorize people into named ethno-cultural collectivities. The transition from ethnic category to group, i.e. from processes of collective categorization to processes of collective self-classification, is instead closely connected with the subjective elements of ethnicity, such as the use of a proper

\footnotetext{
${ }^{8}$ Gat argues that a Latin-Roman nation had been formed in the Western Roman Empire shortly before the empire's disintegration. This he regards as the result of a combination of developments, such as universal citizenship from 211 on, the gradual linguistic Latinization of the subject populations and their Christianization. For the eastern part, he adopts a different stance, since he considers it to have remained ethnically more heterogeneous. Therefore, he regards a shared Roman identity there as weaker; Gat 2013, 121-122.

${ }^{9}$ Kaldellis 2009, 42-119, suggests a longue durée process of emergence of a civic nation in the empire, but, finally, concentrates his argument about a full-blown Roman nation on the post-Justinianic Byzantine Empire.

${ }^{10}$ See Gat 2013, 111-131.

${ }^{11}$ Barth 1969, 14; Malešević 2004, 2-3.

${ }^{12}$ R. Jenkins 2008, 49.
} 
ethnonym, a myth of common ancestry, notional attachment to a historic land of origin as well as reference to common symbols and values. ${ }^{13}$

On the other hand, nationhood, as the predominant form of collective identity in the modern era, refers to identification with and loyalty to the nation as a community which is culturally-territorially circumscribed and politically united, and which is perceived as the principal unit of human solidarity and political legitimacy. ${ }^{14}$ No matter whether the image of the national group is officially constructed and propagated in ethnic (common descent and historic culture) or in civic (egalitarian citizenship) terms. ${ }^{15}$ Here lies in my view an important difference that speaks against an understanding of the two concepts as a priori overlapping in a diachronic perspective for the sake of analytical sharpness.

Ethnicity, as a discourse of categorization or self-classification to an, often non-stable and non-coherent, collectivity of common culture, in the pre-modern era refers in principle to an apolitical vision of community. ${ }^{16}$ A person's categorization or sense of belonging to a group of common culture needed not principally inform his/her political loyalty, insofar as the latter was not preconditioned by congruence between the cultural and the political unit. Nationhood, instead, is interrelated with the transition of the vision of political sovereignty and loyalty from the centripetal and hierarchical discourse of kingship or empire to the discourse of the horizontal nation as the sovereign, autonomous and politically united community of the people. This transition made common cultural identity a precondition for political loyalty, thus dictating the need for cultural homogenization of all members of the political community on the basis of a dominant ethnic (where this is the case ${ }^{17}$ ) or non-ethnic culture. ${ }^{18}$

In this regard, it is important to stress that national identity is intrinsically bound to nationalism not only as a political movement which in the wake of the cumulative bureaucratization of coercion during the early modern era conditioned the emergence of nations and nation-states, but - most importantly - as a dominant operative ideology within modern societies, which determines the continuous self-identification with the nation as the principal unit of political legitimacy, thus ensuring the endurance of national communities as real groups of mass political loyalty. ${ }^{19}$

\footnotetext{
${ }^{13}$ On social category and social group in relation to ethnicity, see R. Jenkins $2008,55-58$. On the distinction between objective and subjective elements of ethnic identity, see A. Smith 1991, 21-23.

${ }^{14}$ Malešević 2013, 75; cf. Brubaker 2004, 116.

${ }^{15}$ These two basic conceptions of the nation are often not mutually exclusive but rather intertwined, see A. Smith 2004a, 203.

${ }^{16}$ Breuilly 1996, 150-154.

${ }_{17}^{17}$ Smith 1991, 39; Smith 2004b, 19-21; Kaufmann 2004, 2-4.

${ }^{18}$ Wimmer 2008, 990-991.

${ }^{19}$ On nationhood as a dynamic process of self-identification which is reproduced quasi on a daily basis through the operative ideology of 'banal' nationalism, see Malešević 2006, 83-108.
} 
In light of this, the configuration of a nation and a nation-state respectively in the medieval era cannot be simply attested on the grounds of a rough congruence between the usually fluctuating limits of enforceable authority of a ruling élite over a certain territory and its population, and this élite's ethnic or cultural discourse. Even if we were to accept the methodologically vulnerable argument that the silence of the illiterate or semi-illiterate masses regarding their own identity should not be taken to reflect a 'big ditch' between their culture and that of the social élite, ${ }^{20}$ we should also consider that common cultural markers do not by themselves a priori configure, and therefore testify to, nationhood as loyalty to the vision of a politically united, autonomous, and culturally homogenous community. ${ }^{21}$

Therefore, before engaging in a debate as to whether the political or ethno-cultural categorization of subject masses in élite discourses also reflects the latter's self-identification or not, we should first focus on the form and content of the projected vision of political community by the élites. This can help us tell the difference between various forms of peoplehood, such as the horizontal and boundary-oriented political community of the nation or a hierarchical and centripetal imperial or regnal political order or, for that matter, a politically non-united ethno-cultural (ethno-linguistic, ethno-religious) collectivity.

2. Roman discourse in early-medieval Byzantium

For a better understanding of the development of the form and content of Romanness in the early medieval East Roman Empire, one needs to look back at the late Roman period wherefrom Byzantine Romanness directly stemmed. In the late empire, Romanness as a collective identity had encompassed regional and ethno-cultural diversity, and supplanted it to a homogenizing political discourse of loyalty/subjectivity to the centralized political rule of the Roman imperial office. ${ }^{22}$ This political discourse was underpinned by a dominant quasiuniform Greco-Latin élite culture. As has been pointed out, by the late Roman period the vision of the Roman community had acquired a geopolitical character, insofar as its boundaries were demarcated by the current boundaries of the imperial office's enforceable authority and the empire's indigenous populations were categorized as Roman in an allinclusive manner, while Romanness was gradually but incrementally bound to a Christian

\footnotetext{
${ }^{20}$ A. Smith 2004a, 206-207.

${ }^{21}$ A 'Spezialforschungsbereich' called Visions of Community, based in Vienna under the direction of Walter Pohl, has been working on these and related questions since 2011. See also the collected volume of the same name, Pohl/Gantner/Payne 2012.

${ }^{22}$ Pohl 1998a, 1; on the multiple facets of Roman identity in the empire, see now Pohl 2014, 406-418.
} 
identity discourse that transcended the social strata. ${ }^{23}$ By the reign of Justinian I, Christian identity was established as the predominant cultural marker of Romanness.

Justinian's Roman-Christian Empire underwent an extensive transformation during the long seventh century. This pertained to the further contraction of imperial authority to the heartlands of the eastern empire, namely the southern Balkans and Anatolia, and the linguistic Hellenization of the Roman power élite, which gave an end to the linguistic divide between this élite and the largely Greek-speaking populations of the empire's contracted territories. These developments inevitably pose some questions regarding a potential change in the form and content of Byzantine Romanness. Was there a shift towards an ethnic vision of the Rhomaioi within a mini-empire which had apparently become culturally more homogenous?

A look at the evidence of Byzantine historiography after the historiographical pause of the so-called 'dark centuries' (early seventh to late eighth centuries) shows that the eradication of the cultural divide between Latin and Greek did not bring about any major change in the form and function of Roman discourse. Byzantine Romanness maintained the main traits of an inclusive regnal discourse of loyalty to the centralized rule of the Roman imperial office of Constantinople. Within this framework, the sources testify to practices of contradistinction of common Roman subjects as well as of members of the élite and emperors according to their classification to, and origin from, one of the various ethno-cultural collectivities in the geopolitical sphere of the empire, such as Armenian, Slavic, Bulgar, Vlach, and others. ${ }^{24}$

The social function of these discourses of ethno-cultural contradistinction needs to be assessed against any misleading conflation of the concepts of ethnicity and nationhood. Ethno-cultural diversity refers, here, not to diverging political loyalties, especially on the level of well-acculturated members of the social élite whose political identity had an active, participatory character. It reflects rather the potential of people to classify themselves and others into groups that were demarcated through various highlighted cultural markers within a political order which remained far from being culturally homogenous at the level of subject populations, and whose élite ideology did not seek to conflate political loyalty with a notion of Roman peoplehood by descent and shared historic cultural markers. ${ }^{25}$.

The lack of interest and intention on the side of the power élite of Constantinople to use the apparently enhanced cultural homogeneity (single lingua franca, Chalcedonian orthodoxy) in order to construct and project an image of the Rhomaioi as an ethnic group

\footnotetext{
${ }^{23}$ Inglebert 2002, 241-260; on the role of religion in late Roman identity cf. Averil Cameron 1991, 30.

${ }^{24}$ Cf. Koder 1990.

${ }^{25}$ On the lack of a myth of common ancestry in Byzantine identity discourse, cf. Magdalino 1991, 6.
} 
after the watershed of the seventh century cannot be approached separately from this élite's political objective to maintain as predominant a certain vision of political community - the vision of a centripetal and hierarchical political order, membership to which was primarily determined by loyalty and/or subject status to the centralized rule of the city-state of New Rome and its emperor.

This political objective dictated the ethnically neutral fashion in which the Greek koine was now presented as a distinct cultural marker of Byzantine Romanness. Theophanes the Confessor, writing at the beginning of the ninth century, describes in his Chronographia the main requirements for someone to become a member of the Byzantine élite, i.e. to become Roman. In his report on the unfulfilled plan of imperial intermarriage between Constantine VI and the daughter of Charlemagne, the author observed that the bride 'should be taught the letters and the language of the Greeks (Graikoi) and should be educated in the customs of the rule of the Romans (Rhomaioi) ${ }^{26}$ Greek was now considered as the language of the Romans (Rhomaion glotta, Rhomaion phone) ${ }^{27}$, which as a lingua franca transcended social strata and regional/ethnic boundaries within the imperial realm,. ${ }^{28}$

However, Theophanes' mindful distinction between the cultural markers (letters and language) of the Greeks and the political customs of the Romans reflects the dominant ideological disposition among the members of the Byzantine social élite, who did not conceive and propagate this linguistic change in ethnic terms, i.e. as a means of historical identification of the Rhomaioi with the ancient Hellenic community. Up to the high Middle Ages, the dominant view of the East Roman community's past was exclusively determined by the notion of unbroken continuity between Rome and Constantinople as new Rome, which linked medieval East Roman peoplehood to the history of the political culture of the Roman city-state ${ }^{29}$.

Within this framework, Theophanes' statement also pinpoints that regnal Romanness, as a shared identity within the imperial realm, was not confined to the Graikoi, i.e. the members of the ethno-linguistic collectivity of native Greek-speaking Chalcedonian Christians. This is made evident, if one looks at the rare use of the ethnonym Graikoi by Byzantine authors in this period, which was not intended to designate the Eastern Romans in a collective manner

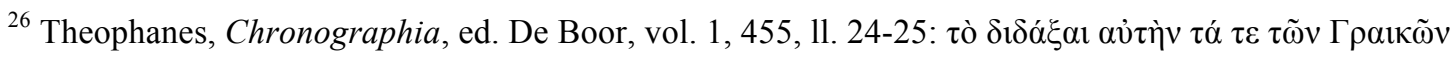

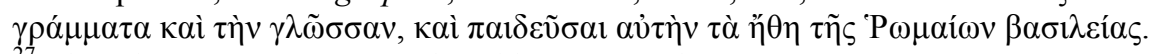

${ }^{27}$ Theophanes Continuatus, ed. Bekker, 308 and 407.

${ }^{28}$ On the linguistic identity of the Byzantines see Koder 2012; cf. Dagron 1994.

${ }^{29}$ Markopoulos 2006, 276-297
} 
(as an alternative to the ethnonym Rhomaioi) but to distinguish between different ethnolinguistic groups of Roman subjects ${ }^{30}$

A statement in the Vita of St Clement of Ochrid, written by the Byzantine bishop of Ochrid Theophylactus in the late-eleventh century, provides a useful insight into the Byzantine élite's strategies of cultural contradistinction of the emperor's subjects within the normative framework of geopolitical Romanness well into the high Middle Ages. The author distinguishes between the land of the Bulgars (Boulgaroi) and the land of the Greeks (Graikoi) in his text, ${ }^{31}$ even though during the lifetime of the saint (mid-ninth to early-tenth centuries) the Bulgars had an independent realm and therefore the distinction should refer to the land of the Bulgars with the land of the Romans, according to the normative Byzantine discourse of the time that reasonably followed the boundaries of Roman political authority. However, the discourse of the Vita is obviously influenced by the fact that, when the bishop was writing, the Bulgars had, for half a century (since 1118), already been subjects of the emperor, i.e. members of the imperial polity, so that their lands and geopolitical status were considered equally Roman as those of the Greek-speaking populations. For this reason, the contradistinction of populations was not determined by the vision of two political communities, i.e. Bulgar vs. Roman, but of cultural diversity, i.e. Bulgar vs. Greek, under the overlapping status of regnal Romanness. ${ }^{32}$

In this respect, it is noteworthy that early-medieval written evidence from the Bulgar realm testifies to a Bulgar preference to the ethnonym Graikos (Greek), instead of Rhomaios (Roman), by the designation of the Eastern Romans. ${ }^{33}$ The use of the former ethnonym seems to have been predominant among the other Slavic peoples of the Balkans as well, should we consider the textual evidence in their languages that originates, however, from the late Middle Ages. This ethnonymic preference of the Slavic people that contradicts with the Byzantines' self-classification as Romans seems to be related to two facts: First, the Slavs had settled on imperial territory, where the Greek ethno-linguistic collectivity was predominant; and second, the Roman imperial power made consistent effort to subjugate and thus integrate them into

\footnotetext{
${ }^{30}$ The ethnonym Graikoi as a designation of a part of the eastern Roman masses in Byzantine texts of this period cannot be considered as evidence that these populations identified themselves with the Ancient Hellenes and their historic culture, as has often been postulated, since all socio-ideological mechanisms that could produce such a notional link were missing. The meaning of Graikoi in a contemporary context rather indicates the changing content of ethnonyms which do not testify to an essential continuity of ethnic identities; cf. Stouraitis 2014, 210-212.

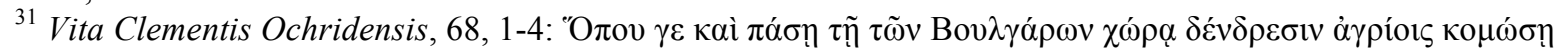

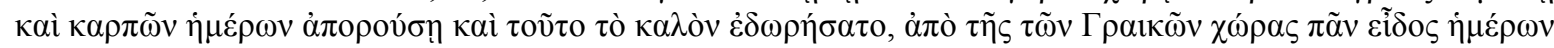

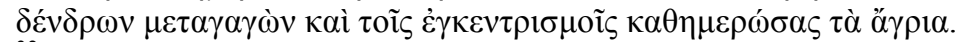

${ }^{32}$ Cf. a similar discourse of contradistinction between the Graikoi and the Slavs in Constantine Porphyrogenitus, De Administrando Imperio c. 49, 11. 4-9, ed. Moravcsik, trans. Jenkins, 228.

${ }^{33}$ Tapkova-Zaimova 1984, 453-460.
} 
centralized Roman rule. Conversely, by the interaction between the Byzantines and the Arabs in the East, where the cultural conditions were different and the political boundaries more clearly drawn, especially after the rise of Islam, the Muslims adopted the Byzantine selfdesignation and named them as ar-Rūm (Romans). ${ }^{34}$

The predominantly geopolitical character of the Roman vision of community in the postseventh-century 'Hellenized' East Roman Empire is also reflected in the Byzantine image of Roman territory. The image of Roman lands - conceptualized with terms such as Romania

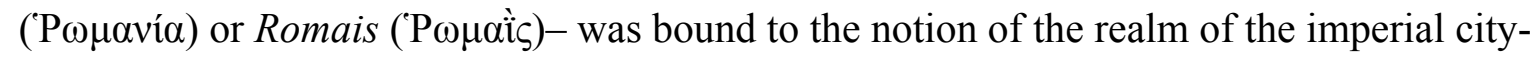
state of Constantinople and therefore remained as fluctuating as the borders of imperial authority in the identity discourse of Byzantine authors. For instance, in the Vita of the Forty Martyrs of Amorion, written in the late ninth or early tenth century, the author refers to the radical contraction of the boundaries of Roman rule during the Muslim expansion in the seventh century and later designates the contracted lands currently under Roman authority as Romania. ${ }^{35}$ In the opposite direction, the historiographical work known as Theophanes Continuatus, written around the mid-tenth century, informs us that the conquest of Muslim cities, fortresses and lands in the East by the army leader John Kourkouas during the second quarter of the tenth century doubled the (territorial) size of the Romania, i.e. the realm of the Roman emperor's enforceable authority. ${ }^{36}$ The reconquered lands were of course regarded as ancient possessions of the Roman imperial rule, i.e. as former parts of the Romania.

The fluctuating boundaries of regnal Romanness need to be examined in relation to the role of religious, i.e. Christian, identity in providing a common cultural background for Roman subjects beyond the level of the educated élites. In particular, one needs to consider the central role of a common religious identity in facilitating the integration of new, ethnoculturally diverse populations into the Roman body politic as a result of the expansion of imperial authority during the later phase of the early Middle Ages (ninth and tenth centuries). The conclusion of the process of Christianization of the empire's masses by the end of late antiquity had an ample effect on Roman identity discourse.

In post-seventh-century Byzantine historiography, the designation Christian was employed as an equivalent of the designation Roman to collectively classify the emperor's subjects. The Short History of Patriarch Nikephoros of Constantinople, written towards the end of the eighth century, begins with the following statement on the reign of emperor Phokas (602-610): 'When he had assumed power the situation of the Christians came to such a pitch

\footnotetext{
${ }^{34}$ Koder 2012, 7.

${ }^{35}$ De XLII Martyribus Amoriensibus narrationes et carmina sacra, ed. Vasil'evskij/Nikitin, 63, 6 and 75, 35.

${ }^{36}$ Theophanes Continuatus, ed. Bekker, 426, $24-427,4$.
} 
of misfortune that it was commonly said that, while the Persians were injuring the Roman realm from without, Phokas was doing worse (damage) within'. ${ }^{37}$ In a similar manner, the same author as well as Theophanes the Confessor describe in their texts the internal armed conflict over the throne between the emperor Constantine V and his general Artabasdus, which upset the Roman realm for three years, as a 'civil war' among the Christians (as our sources put it). ${ }^{38}$

These statements indicated the configuration of an alternative image of East Roman peoplehood in ethno-religious terms due to the predominance of Christian identity within the imperial realm. The function of this image should be measured, however, against the actual potential of Christian discourse to create a culturally exclusive boundary for Romanness within a broader geopolitical sphere, in which the boundaries of Roman and Christian identity did not coincide. Considering that Christian identity was able to transcend regional and ethnic boundaries in an overlapping manner, similarly to Romanness as a regnal identity, its conflation with the latter in the identity discourse of the Constantinopolitan élite was there to maintain and reinforce its inclusive geopolitical character rather than to undermine it in favour of ethnic exclusiveness.

The identity discourse of Theophanes Continuatus provides a characteristic example of the role of common religious identity in facilitating the integration of new populations into the eastern Roman body politic. The author of the text describes the voluntary return to Byzantine rule during the reign of Basil I (867-886) of Slavic tribes in the Balkans that had rebelled against it. According to the report, those Slavs who had maintained the common religion as well as those who had abandoned it requested that they might submit to the benevolent yoke of Roman power again and be counted among the subjects of its shepherd. ${ }^{39}$ The Byzantine emperor dispatched priests in order to restore the Slavs to their former faith and when they had all partaken of holy baptism and reverted to the status of Roman subjects, his realm was restored in those parts. ${ }^{40}$

The life of St Antony the Younger provides further insights into the significance of common religious identity, as opposed to regional or ethno-cultural background, for the integration of a person into the Byzantine social order, i.e. by the process of becoming

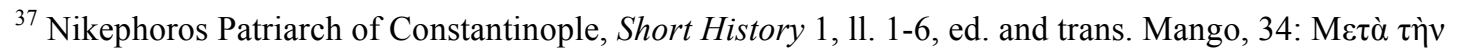

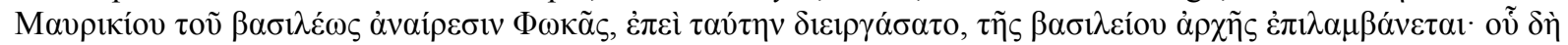

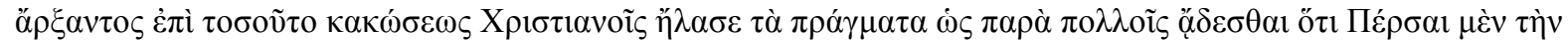

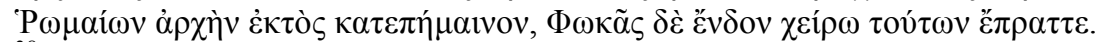

${ }^{38}$ Nikephoros Patriarch of Constantinople, Short History 65, 11. 14-17, ed. and trans. Mango, 134-136; cf. Theophanes, Chronographia, ed. De Boor, vol. 1, 418, 11. 7-11.

${ }^{39}$ Vita Basilii Imperatoris, 54, 11. 1-15, ed. and trans. Ševcenko, 194.

${ }^{40}$ Vita Basilii Imperatoris, 54, 11. 20-27, ed. and trans. Ševcenko, 196.
} 
Roman. The saint was born outside the Byzantine realm as a native Christian of Palestine in 785, into a family that was well off. ${ }^{41}$ This probably enabled him to acquire some education and to be raised bilingual, for he could speak both Greek and Syriac (meaning probably Arabic by this time) according to the evidence of the Vita $^{42}$ In the early years of the ninth century, after the death of his parents, it is reported that he abandoned the Caliphate with a group of other Christians and crossed to the Byzantine realm. Within a short period of time, he managed to become a close associate of the general and governor of the province (thema) Kibyrrhaioton in south-western Asia Minor. The latter intervened at the emperor in Constantinople and arranged the saint's appointment as a deputy-governor in the same province. ${ }^{43}$ This development sealed Antonios' membership to the provincial Roman élite.

Both aforementioned cases pinpoint the principle role of religious proto-ideology in the process of integration of persons or groups into the East Roman geopolitical discourse, as the main precondition for them (contrary to notions of Roman ethnic descent or indigenousness) to become Roman subjects or even to enter the Roman upper strata. For Antonios, as a nonnative of the empire but as a member of a broader Christian commonwealth that expanded beyond the limits of imperial authority, some level of literacy and knowledge of the Greek language were the main means that facilitated the transition from a status of common Roman subject to becoming Roman in a more participatory political sense by acquiring an important office in the imperial administration. The reported dialogue between the saint and emperor Theophilos (829-842) at the imperial court, in which the former is presented to defend his actions as an imperial officer against the rebel Thomas on behalf of Theophilos' father, Michael II (820-829), reveals the political content of the Romanness of the provincial élite of service as an identity of loyalty to the vision of a centralized imperial order, which was underlined by vested interests in and dependence upon the imperial office. ${ }^{44}$

Within the framework of a centripetal and hierarchical vision of political community, neither ethno-linguistic Greekness nor even Christian orthodoxy (Chalcedonian creed), as constitutive elements of Byzantine élite culture, functioned as criteria of exclusion of persons or groups from acquiring the status and the basic 'rights' of Roman subjects or from becoming members of the Roman élite respectively. The imperial state's limited ability and interest in promoting the cultural or even confessional homogeneity of subject populations in

\footnotetext{
${ }^{41}$ PmbZ, nr. 534.

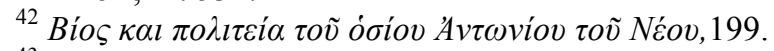

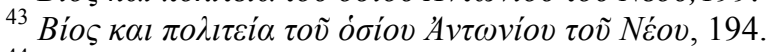

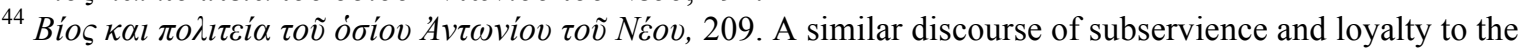
imperial office of Constantinople is found in the text of the provincial magnate Kekaumenos, cf. Koder 2011, 80-81; Stouraitis 2014, 190 ; cf. Haldon 2009, 171-182.
} 
the heartlands of its realm is demonstrated both by its policies of population transfers as well as of territorial expansion between the late seventh and the tenth centuries. The sources testify to a large number of forced transfers of culturally diverse groups, such as the resettlement of large numbers of Slavs from the Balkans to Asia Minor under Justinian II (685-695) and Constantine V (741-775), the movement of large numbers of Armenians and Syrians as well as of populations belonging to the heretic Christian group of the Paulicians from the eastern frontier zone to Thrace in the reigns of Constantine V, Basil I (863-886) and Nikephoros Phokas (963-969). ${ }^{45}$

The people from those diverse ethno-cultural and confessional collectivities not only were considered full members of the producing and tax-paying body of Roman subjects, but also represented a pool of human resources whence the emperor drew recruits for his armies. Moreover, proper education for anyone that could acquire it (along with conversion for those not adhering to the Chalcedonian doctrine), i.e. full-blown acculturation to élite culture, could open the way into the imperial administration, court or provincial, and the social upper strata. The case of the Paulicians who were able to maintain and even diffuse their heretical beliefs in their new areas of settlement for centuries, while they kept being recruited to the imperial armies despite their heretic views, ${ }^{46}$ is indicative of the potential of the masses of common Roman subjects to maintain various identities underneath the homogenizing Roman discourse of Constantinople and the cultural uniformity of the social élite.

On the other hand, the imperial power's policies of territorial expansion, mainly from the mid-tenth to the early-eleventh centuries, were marked by the traditional Roman practice of integrating regional/ethnic élites into the system of empire and the Roman élite of service in order to consolidate the subject status of the populations of those regions. ${ }^{47}$ For instance, during the later phase of Basil II's war for the subjugation of the Bulgar realm (early-eleventh century), the emperor offered Roman titles and offices, i.e. a position in the hierarchical system of empire, to gain the loyalty of a number of local warlords who changed sides. ${ }^{48}$ This practice was facilitated by the common religious identity. After the end of the war and the subjugation of the whole Bulgar realm to the authority of Constantinople, their Roman titles and offices made these Bulgar magnates full members of the provincial élite, whose loyalty to the vision of a politically united community under the imperial rule of New Rome was

\footnotetext{
${ }^{45}$ On transfers of various ethno-linguistic and ethno-religious groups within the empire, see Lilie 1976, 227-254; Ditten 1993, 123-305. On Armenians, Muslims and Paulicians, cf. Lilie 2012.

${ }^{46}$ Anna Komnena, Alexias IV, 4, 3, ed. Reinsch/Kambylis, 126-127; cf. Lilie 2012, 313-314.

${ }^{47}$ On such practices in the East during the expansionary policies of the tenth century, see Holmes 2001, 45-50.

${ }^{48}$ See John Scylitzes, Synopsis historiarum, Basil II, ed. Thurn, 342-343, 344, 346, 353, 357-358, 359.
} 
empire-wide determined by dependence upon and vested interests in the imperial office of Constantinople.

Similar practices are testified throughout the period of the ninth and tenth centuries with Armenian magnates that entered Byzantine service and became full members of the Byzantine élite. The case of the Armenian lord Senacherim (Yovhannēs s. Senek'erim) during the reign of Basil II represents a typical example. In 1021/22, the emperor annexed his lands (Vaspourakan), honoured him with the title of Roman patrician and made him general of Cappadocia in Anatolia, where he resettled with his family and retinue. ${ }^{49}$ The Miaphysite confession of these Armenians points to the flexibility that characterized both sides in the matter of orthodox religious identity, when it came to questions of political loyalty.

\section{Terminological aspects of the early-medieval East Roman community}

An insightful aspect of the development of Roman identity discourse in Byzantium is provided by the terminology of Byzantine historiography regarding the early-medieval East Roman community. The terms used by Byzantine authors to conceptualize human collectivities were genos and ethnos (meaning race/kin/tribe/origin and people/company/class respectively). Both terms could be employed to denote different kinds of human or even nonhuman groupings that were distinguished according to certain common characteristics. The combination of genos or ethnos with an ethnonym, however, was a standardized form to conceptualize a people. In this regard, it is important to point out that both terms were used interchangeably by Byzantine authors to designate communities of common kinship and shared cultural markers, with or without centralized political organization, but also larger collectivities that were subdivided into various ethnies (e.g. Latinon genos).

If we turn, now, to the conceptualization of the Byzantine, i.e. Roman, community in the historiography of the period after the cultural and territorial transformation of the seventh century, it is noteworthy that Byzantine authors of both chronicles and histories avoided the designation of the eastern Romans as genos or ethnos. In the historiographical texts of the late eighth, ninth and tenth centuries, the term Rhomaion ethnos is fully absent in a contemporary sense, ${ }^{50}$ whereas the term Rhomaion genos is testified only once in the history of Theophanes Continuatus (mid-tenth century). Instead, the predominant mode of contradistinction referred to the juxtaposition of the realm of Roman rule (Rhomaion arche, Rhomaion basileia) or, in

\footnotetext{
${ }^{49}$ PmbZ 2014, nr. 27008.

${ }^{50}$ There is only one reference to Rhomaion ethnos in the ninth-century chronicle of George Monachos that refers to the pagan Romans of the time of Christ; cf. George Monachos, Chronicon, ed. de Boor, vol. 1, 318, 1. 16.
} 
the least cases, the Roman imperial polity (Rhomaion politeia $)^{51}$ with a foreign ethnos or genos. This predominant terminological stance in early-medieval Byzantine historiography seems to be interrelated with the official vision of the Roman community as a political entity that was demarcated by the boundaries of imperial authority in élite imagery. A closer look at the content of the term Rhomaion genos in the single case that this is used in the discourse of Theophanes Continuatus is indicative.

The report concerns a statement of emperor Theophilos (829-842) that the Rhomaion genos was honoured and admired by all peoples (ethne) due to its superior knowledge. ${ }^{52}$ In a similar context in another part of the text, the author refers to those things that made the Rhomaion basileia (Roman rule) admirable and caused the awe of foreign people. ${ }^{53}$ The semantically overlapping use of the terms Rhomaion genos and Rhomaion basileia in similar contexts in the text indicates that the employment of the former term was hardly intended to downgrade the Roman community to the image of community of common kinship equally to the barbarian peoples (ethne) outside the boundaries of the imperial polity. It rather seems to be referring to the politically and culturally superior ruling genos of Constantinople - New Rome, whose authority circumscribed the boundaries of the Roman community as the boundaries between civility and barbarity. This is further supported by the author's reference to emperor Romanos II as the ruler of peoples (ethne) in the text. ${ }^{54}$ This reference reflects a common topos of Byzantine political ideology that was a product of the Byzantine approach to the Roman community's historical past. According to this, the imperial rule of Rome had united the various peoples (ethne) of the Oecumene under its pacifying and civilizing political yoke. $^{55}$

It is in this ideological context that one needs to evaluate the absence from the historiography of the late eighth, ninth and tenth centuries of a full-blown image of Roman ethnicity. In Byzantine discourse, the ethnic content of the terms genos or ethnos when it came to the conceptualization of foreign peoples (e.g. ethnos Armenion) is demonstrated by the complementary notion of someone being a member of the community by descent (e.g. Armenios to genos). Conversely, the early-medieval vision of Roman peoplehood was not underlined by the notion of Romanness by descent (Rhomaios to genos). A notorious example provides the story of Emperor Basil I, the founder of the longest imperial dynasty in

\footnotetext{
${ }^{51}$ On the political-territorial aspect of the term politeia, see Magdalino 2013, 39; cf. Sode 1994,160-61.

${ }^{52}$ Theophanes Continuatus, ed. Bekker, 190, 11. 18-21.

${ }^{53}$ Theophanes Continuatus, ed. Bekker, 95, 1. 19-96, 1. 8.

${ }^{54}$ Theophanes Continuatus, ed. Bekker, 473, 1. 4.

${ }^{55}$ Cf. George Monachos, Chronicon, ed. de Boor, vol. 1, 296, 11. 8-16; Constantine Porphyrogenitus, Narratio de imagine Edessena 4, ed. von Dobschütz; Idem, De thematibus, ed. Pertusi, I, 8-21.
} 
Byzantium. Even though he was a native of the empire from the region of Thrace, the histories of this period, including his biography (Vita Basilii) which was a part of the historiographical corpus of Theophanes Continuatus and was written by order (if not by the hand) of his grandson emperor Constantine VII, present him as Armenian by origin. ${ }^{56}$

Apart from the fictitious story about this emperor's noble descent from the regnal family of the Arsacids, Basil's family origin probably went back to the large number of Armenians that had been transferred by Constantine V (741-775) from the eastern frontier to Thrace ${ }^{57}$. This means that Basil belonged to the third generation of Armenians and therefore he should be considered as fully integrated into the local culture of Byzantine Thrace. ${ }^{58}$ His extraordinary course of social ascent from a simple Roman subject of Armenian background to a member of the Constantinopolitan élite, ${ }^{59}$ and finally to emperor of the Romans provides an insight into the various strategies of identification and contradistinction of people within a social order, in which the élite vision of Roman peoplehood, i.e. of a Roman political community marginalized issues of indigenousness and ethnic descent.

The author of his Vita reports that Basil, as an already fully integrated member of the imperial court, had strong bonds of friendship with the patrician Constantine due to their common Armenian origin. ${ }^{60}$ This discourse of ethno-cultural ties as a part of the social identity of two well-acculturated members of the Constantinopolitan élite was by no means intended to dispute their Roman identity, i.e. their principal self-identification as Romans and their loyalty to the political culture of New Rome, the degree of which was primarily conditioned by a person's position in the hierarchical Roman social order and assimilation to the Roman hegemonic discourse. Nonetheless, their classification as members of a demarcated ethno-cultural collectivity within the Roman body politic is rather indicative of a social reality of cultural diversity among the masses of common Roman subjects.

The ideological disposition of the early-medieval Byzantine élite that did not seek to bind Romanness as a political discourse to an exclusive image of Roman peoplehood based on common descent and shared historic cultural markers provides a useful point of departure to interpret the use of terminology about the eastern Romans in this period that bears strong ethnic connotations. In the beginning of the reign of emperor Michael II (820-829), the sources report on the rebellion of the sub-general of the division (thema) Anatolikon Thomas

\footnotetext{
${ }^{56}$ Vita Basilii Imperatoris 2, 11. 1-3, ed. and trans. Ševcenko, 10.

${ }^{57}$ Lilie 1976, 248-249; Ditten 1993, 184-186.

${ }^{58}$ Cf. Lilie 2012, 306-307.

${ }^{59}$ Cf. Beck 1965, 6-12.

${ }^{60}$ Vita Basilii Imperatoris 12, 11. 24-27, ed. and trans. Ševcenko, 48; Genesii regum libri quattuor, eds. Lesmüller-Werner/Thurn, 4, 1. 24; John Scylitzes, Synopsis historiarum, Basil I, ed. Thurn, 115
} 
and, in a typical fashion, designate the three-year war between him and the emperor as an emphylios polemos (internal armed conflict). ${ }^{61}$ This was due to the fact that his rebellion was aimed at the imperial throne, which he claimed as a Roman officer relying on the loyalty of Roman units next to allied foreign forces. Considering that the literary meaning of the term emphylios is 'within the same race', whereas the term phylon (race) was often used as a synonym of the term ethnos by Byzantine authors, ${ }^{62}$ it is noteworthy that the author highlights Thomas' Slavic origin, even though he was a native of the empire from Asia Minor. ${ }^{63}$

This choice of identity discourse is most telling about the Byzantine use of the term emphylios as well as of other terms that bore connotations of common kinship, such as homophylos (of the same race) or homoethnes (of the same people), when these terms were employed to refer to Roman subjects. Despite an apparent higher degree of cultural homogeneity in the post-seventh-century empire's heartlands due to the predominance of the Christian religion and the Greek language, the Byzantine notion of emphylios polemos (internal armed conflict) was not informed by the image of a people of common ethnic origin. Instead, it was used to conceptualize the participants' regnal status as Roman subjects and their identity of loyalty to the political culture of Constantinople's centralized imperial rule, which was underlined by a common religious background.

It is against this dominant vision of regnal Romanness that the deprecatory characterization of Thomas as a barbarian in the text of Theophanes Continuatus needs to be measured. ${ }^{64}$ Thomas' barbarian identity cannot be considered to refer to geopolitical foreignness, for he was a Roman officer born and raised in the empire that claimed the throne as Roman. Moreover, it cannot be attributed to a generic stance of Constantinopolitan historiography towards Roman subjects of Slavic origin as racially or culturally inferior, for in the same text we find references to the Slavic origin of Roman officials at the imperial court that have no similar deprecatory character. ${ }^{65}$ Therefore, the rebel's denunciatory characterization as a barbarian in historiographical hindsight seems rather to have resulted from his humble social origin, as the son of ignoble Slavic parents, in relation to his relevant lack of full acculturation to the dominant culture of the Roman élite. ${ }^{66}$ As opposed to the

\footnotetext{
${ }^{61}$ Theophanes Continuatus, ed. Bekker, 49, 11. 20-21.

${ }^{62}$ Cf. Stephanus of Byzantium, Ethnika, ed. Meineke, 675, 11. 1-2. The word emphylios originates from the word phylon which meant the same as the word ethnos: phylon is the ethnos, which stems from phyle (tribe/race) or of which phyle originates. Combined become emphylos and emphylios.

${ }^{63}$ Theophanes Continuatus, ed. Bekker,, 50, 11. 19-21.

${ }^{64}$ Theophanes Continuatus, ed. Bekker, , 53, 11. 1-2.

${ }^{65} \mathrm{Cf}$. the neutral reference to the Slavic origin of Damianos, a patrician and parakoimomenos (chamberlain) of Emperor Michael III; Theophanes Continuatus, ed. Bekker,, 234, 11. 7-9.

${ }^{66} \mathrm{Cf}$. the semi-barbarian status attributed by Constantinopolitan authors to Emperor Phocas (602-610), who usurped the throne as a humble centurion; Theophylact Simocatta, Historiae 8, 10, 4, ed. de Boor / Wirth, 303.
} 
previous case of Basil I who, even though of humble social origin as well, had managed to become a full member of the Constantinopolitan élite before usurping the throne, Thomas had worked his way up into the hierarchy of the Byzantine social order through a career in the army - the main means for illiterate or semi-illiterate persons of lower social status to claim a share of the Roman discourse of power. The stance of Constantinopolitan historiography towards him provides an insight into the exclusive function of élite culture within a homogenizing political discourse. Moreover, it points to the differentiated potential for, and degree of, acculturation of the members of the empire's various ethno-linguistic and/or ethnoreligious collectivities to the dominant Constantinopolitan culture.

For the emergence of a full-blown image of eastern Roman ethnicity in Byzantine historiography, one needs to wait until the late-eleventh century. John Skylitzes, writing probably in the late 1170s, is the first Byzantine historiographer to make use of the notion of a person being Roman by birth (Rhomaios to genos) for a native of the empire's heartland. ${ }^{67}$ This discourse reappears then in the historiographical works of John Kinnamos and Niketas Choniates in the late twelfth century, ${ }^{68}$ where it is combined with a digressing image regarding the boundaries of the Roman community. As opposed to the normative view of the historiography of the previous centuries, which was determined by the fluctuating boundaries of imperial authority of New Rome, now the eastern Romans were also envisaged in different and more exclusive terms as a group of common kinship and shared cultural markers, whose members needed not be subjects of the politeia, i.e. of the Constantinopolitan emperor's realm. ${ }^{69}$ This is indicated by the designation as Roman in Constantinopolitan historiography of indigenous Greek-speaking Christian populations in the territories of Asia Minor that were outside the radically contracted Roman realm of the emperor of Constantinople. ${ }^{70}$

However, the gradually emerging ethnic vision of eastern Romanness stood in contradiction with regnal Romanness as an inclusive political discourse of loyalty to the centralized rule of the imperial city-state of New Rome and its emperor. ${ }^{71}$ The definitive

\footnotetext{
${ }^{67}$ The reference concerns a Byzantine monk named Methodios that was hired by the Bulgar ruler Boris as a

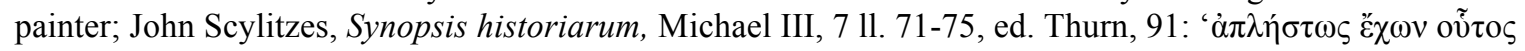

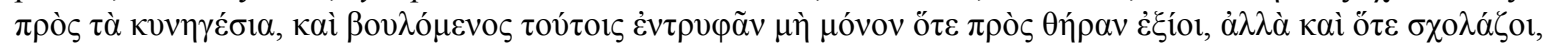

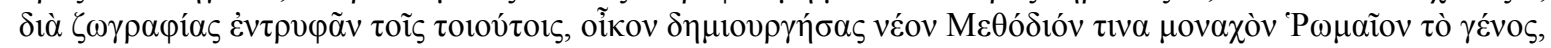

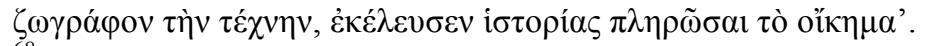

${ }^{68}$ See three references in John Kinnamos, Epitome, ed. Meineke, 56, 251 and one reference in Nicetas Choniates, Historia, ed. van Dieten, 37, 190.

${ }^{69}$ In the previous centuries, Byzantine historiography used Roman discourse to designate people outside the limits of the empire mainly for prisoners of war (usually Roman soldiers), but not for indigenous populations of territories that represented former parts of the Roman realm. The main identity link between those populations and the empire was provided by the common Christian religion.

${ }^{70}$ John Kinnamos, Epitome, ed. Meineke, 22, 63, 296; cf. also a similar reference in Anna Komnena, Alexias XI, 8, 2, ed. Reinsch/Kambylis, 346.

${ }^{71}$ Stouraitis 2014, 215-216.
} 
disintegration of the centralized imperial rule of Constantinople in 1204 sealed the consolidation of an image of a politically fragmented Roman ethnic group. ${ }^{72}$ This development was complemented by a process of renegotiation of the élite's view of the eastern Roman community's past. The multiplying statements of educated élite members that linked the Rhomaioi to the Ancient Greeks as bearers of their historic culture, which culminated in the temporary salience of a myth of Hellenic descent in the court of the socalled successor-state of Nicaea in the mid-thirteenth century, bear witness to the configuration of a hybrid version of Roman ethnic identity in late Byzantium. ${ }^{73}$

\section{Bibliography:}

\section{Primary Sources:}

Anna Komnene, Alexias, ed. Diether R. Reinsch / Athanasios Kambylis, Corpus Fontium Historiae Byzantinae 40/1, Berlin, 2001.

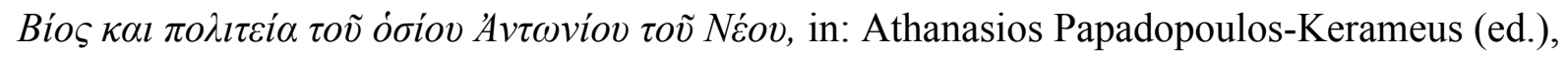

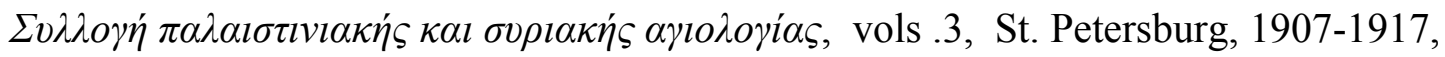
vol. 1, 186-216.

Constantine Porphyrogenitus, De administrando imperio, ed. Gyula Moravcsik, Corpus Fontium Historiae Byzantinae 1, Washington/D.C., 1967.

Costantine Porphyrogenitus, De thematibus, ed. Agostino Pertusi, Studi e Testi 160, Vatican City, 1952.

Constantine Porphyrogenitus, Narratio de imagine Edessena, in: Ernst von Dobschütz (ed.), Christusbilder. Untersuchungen zur christlichen Legende, Leipzig, 1899, 39-85.

George Monachos, Chronicon, ed. Carl de Boor, 2 vols, Leipzig 1904.

John Kinnamos, Epitome rerum ab Ioanne et Alexio Comnenis gestarum, ed. Augustus

Meineke, Corpus Scriptorum Historiae Byzantinae 13, Bonn, 1836.

John Scylitzes, Synopsis historiarum, ed. Ioannes Thurn, Corpus Fontium Historiae

Byzantinae 5, Berlin, 1973.

Nikephoros Patriarch of Constantinople, Short History, text, translation, and commentary by Cyril Mango, Corpus Fontium Historiae Byzantinae 13, Washington/D.C., 1990.

Nicetas Choniates, Historia, ed. Jan-Louis van Dieten, Corpus Fontium Historiae Byzantinae 11, 1, Berlin, 1975.

Stephanus of Byzantium, Ethnika, ed. Augustus Meineke, Berlin, 1849, reprinted 1958.

\footnotetext{
${ }^{72}$ Page 2008.

${ }^{73}$ Koder 2003, 310-313; Angelov 2005, 299-303; Stouraitis 2014, 212-222.
} 
Theophanes, Chronographia, ed. Carl De Boor, 2 vols, Leipzig, 1883-1885, reprinted Hildesheim, 1963.

Theophanes Continuatus, ed. Immanuel Bekker, Bonn, 1838.

Theophylact Simocatta, Historiae, ed. Carl de Boor / Peter Wirth, Stuttgart, 1972.

De XLII Martyribus Amoriensibus narrationes et carmina sacra, ed. B. Vasil'evskij - P.

Nikitin, Zapiski Imp. Ak. nauk po ist.-fil. otdel. VIII, Ser.,VII, St. Petersburg, 1905.

Vita Basilii Imperatoris: Chronographiae quae Theophanis Continuati nomine fertur Liber

quo Vita Basilii Imperatoris amplectitur, ed. Ihor Ševcenko, Corpus Fontium Historiae Byzantinae 42, Berlin, 2011.

Vita Clementis Ochridensis, in: Alexander Milev (ed.), Gruckite zitija na Kliment Ochridski, Sofia, 1966, 76-146.

Joseph Genesius, Iosephi Genesii regum libri quattuor, eds.A. Lesmüller-Werner and J.

Thurn, Berlin 1978.

\section{Secondary Literature:}

Angelov, Dimiter (2005), 'Byzantine Ideological Reactions to the Latin Conquest of Constantinople', in: Angeliki Laiou (ed.), Urbs Capta: The Fourth Crusade and its Consequences, Réalités Byzantines 10, Paris, 293-310.

Barth, Fredrik (1969), 'Introduction', in: Fredrik Barth (ed.), Ethnic Groups and Boundaries, Bergen, 9-38.

Beck, Hans-Georg (1965), 'Byzantinisches Gefolgschaftswesen', in: Sitzungsberichte / Bayerische Akademie der Wissenschaften, Philosophisch-Historische Klasse 5, Munich. Breuilly, John (1996), ‘Approaches to nationalism', in: Gopal Balakrishnan / Benedict Anderson (eds.), Mapping the Nation, London and New York, 146-174.

Brubaker, Rogers (2004), 'In the Name of the Nation: Reflections on Nationalism and Patriotism', in: Citizenship Studies 8, 2, 115-127.

Cameron, Averil (1991), Christianity and the rhetoric of empire: the development of Christian discourse, Berkeley and Los Angeles.

Dagron, Gilbert (1994), 'Formes et fonctions du pluralisme linguistique à Byzance (IXe -XIIe siècle)', in: Traveaux et Mémoire 12, 219-240.

Ditten, Hans (1993), Ethnische Verschiebungen zwischen der Balkanhalbinsel und Kleinasien vom Ende des 6. bis zur zweiten Hälfte des 9. Jahrhunderts, Berliner Byzantinische Arbeiten 59, Berlin. 
Gat, Azar (with Alexander Yakobson) (2013), Nations: The Long History and Deep Roots of Political Ethnicity and Nationalism, Cambridge.

Haldon, John F. (2009), 'Social Élites, Wealth, and Power', in: John F. Haldon (ed.), A Social History of Byzantium, Oxford, 168-211.

Heather, Peter (2005), The Fall of the Roman Empire, London.

Holmes, Catherine (2001), 'How the East was won in the Reign of Basil II', in: Anthony Eastmond (ed.), Eastern Approaches to Byzantium: papers from the Thirty-third Spring Symposium of Byzantine Studies, University of Warwick, Coventry, March 1999, Aldershot, 41-56.

Ichijo, Atsuko / Uzelac, Gordana (eds.) (2005), When is the Nation? Towards an understanding of theories of nationalism, London.

Inglebert, Hervé (2002), 'Citoyenneté romaine, romanités et identités romaines sous l'Empire', in: Hervé Inglebert (ed.), Idéologies et valeurs civiques dans le monde romain. Hommage à Claude Lepelley, Paris, 241-260.

Jenkins, Richard ( $\left.{ }^{2} 2008\right)$, Rethinking Ethnicity, London.

Kaldellis, Anthony (2009), Hellenism in Byzantium: The transformations of Greek identity and the reception of the classical tradition, Cambridge.

Kaufmann, Eric P. (2004), 'Dominant ethnicity: from background to foreground', in: Eric P. Kaufmann (ed.), Rethinking Ethnicity. Majority groups and dominant minorities, London and New York, 1-12.

Koder, Johannes (1990), 'Byzanz, die Griechen und die Romaiosyne - eine „Ethnogenese“ der „Römer“'?', in: Herwig Wolfram (ed.), Typen der Ethnogenese unter besonderer Berücksichtigung der Bayern, vol. 1, Vienna, 103-111.

Koder, Johannes (2003), 'Griechische Identitäten im Mittelalter - Aspekte einer

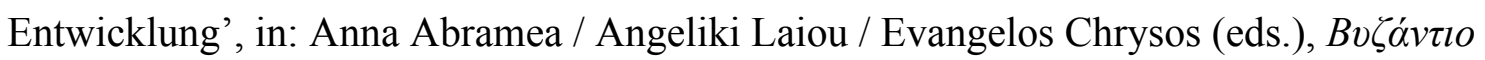

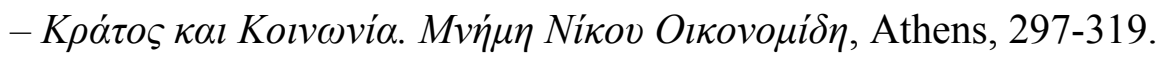

Koder, Johannes (2011), 'Byzantium as seen by itself - Images and mechanisms at work', in: Iliya Iliev / Angel Nikolov (eds.), Proceedings of the 22nd International Congress of Byzantine Studies Sofia, 22-27 August 2011, I. Plenary Papers, Sofia, 69-81.

Koder, Johannes (2012), 'Sprache als Identitätsmerkmal bei den Byzantinern (Auf -isti endende sprachbezogene Adverbien in den griechischen Quellen)', in: Anzeiger der philosophisch-historischen Klasse der Österreichischen Akademie der Wissenschaften $147,2,5-37$. 
Lilie, Ralph-Johannes (1976), Die byzantinische Reaktion auf die Ausbreitung der Araber:

Studien zur Strukturwandlung des byzantinischen Staates im 7. u. 8. Jhd., Miscellanea Byzantina Monacensia 22, Munich.

Lilie, Ralph-Johannes (2012), 'Zur Stellung von ethnischen und religiösen Minderheiten in Byzanz: Armenier, Muslime und Paulikianer', in: Walter Pohl / Clemens Gantner / Richard Payne (eds.), Visions of community in the post-Roman world: The West, Byzantium and the Islamic world, 300-1100, Farnham, 301-316.

Magdalino, Paul (1991), 'Hellenism and Nationalism in Byzantium', in: Paul Magdalino (ed.), Tradition and transformation in medieval Byzantium, Variorum 14, Aldershot. Magdalino, Paul (2013), 'Constantine VII and the Historical Geography of Empire', in S.

Bazzaz/Y. Batsaki/D. Angelov (eds.), Imperial Geographies in Byzantine and Ottoman Space, Cambridge, MA, 23-42.

Malešević, Siniša (2004), The Sociology of Ethnicity, London.

Malešević, Siniša (2006), Identity as Ideology: Understanding Ethnicity and Nationalism, New York.

Malešević, Siniša (2013), Nation-States and Nationalisms: Organization, Ideology and Solidarity, Cambridge.

Markopoulos, Athanasios (2006),'Roman Antiquarianism: Aspects of the Roman Past in the Middle Byzantine Period (9th-11th centuries)', Proceedings of the 21st International Congress of Byzantine Studies, London 21-26 August, 2006 (Plenary Papers, 1), Aldershot, 277-297.

Page, Gill (2008), Being Byzantine: Greek Identity before the Ottomans, Cambridge.

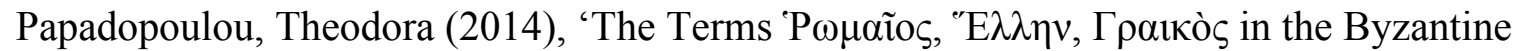
Texts of the first half ofthe 13th century', Byzantina Symmeikta 24, 157-176.

Parfit, Derek (1995), 'The Unimportance of Identity', in: Herbert Harris (ed.), Identity:

Essays based on Herbert Spencer Lectures given in the University of Oxford, Oxford, $13-45$.

PmbZ (2014): Lilie, Ralph J. / Ludwig, Claudia / Zielke, Beate / Pratsch, Thomas / Rochow, Ilse, Prosopographie der mittelbyzantinischen Zeit Online, Databasis De Gruyter. Pohl, Walter (1998a), 'Introduction: Strategies of Distinction', in: Walter Pohl / Helmut Reimitz (eds.), Strategies of Distinction: The Construction of Ethnic Communities, 300800, Leiden 1998, 1-16.

Pohl, Walter (2014), 'Romanness: a multiple identity and its changes', in: Early Medieval Europe 22, 4, 406-418. 
Pohl, Walter / Gantner, Clemens / Payne, Richard (2012), eds., Visions of Community in the Post-Roman World. The Latin West, Byzantium and the Islamic World, 300-1100, Farnham and Burlington, Vermont.

Smith, Anthony D. (1991), National Identity, London.

Smith, Anthony D. (2004a), 'History and national destiny: responses and clarifications', in: Nations and Nationalism 10 (1/2), 195-209.

Smith, Anthony D. (2004b), 'Ethnic cores and dominant ethnies', in: Eric P. Kaufmann (ed.), Rethinking Ethnicity: Majority groups and dominant minorities, London and New York, $15-26$.

Smith, Anthony D. (2005), 'The genealogy of nations: an ethno-symbolic approach', in: Atsuko Ichijo / Gordana Uzelac (eds.), When is the Nation? Towards an understanding of theories of nationalism, London, 94-112.

Smith, Anthony D. (2009), Ethno-symbolism and Nationalism: A Cultural Approach, London and New York.

Sode, C. (1994), 'Untersuchungen zu De administrando imperio Kaiser Konstantins VII. Porphyrogenitus', (Poikila Byzantina, 13), Bonn, 149-260.

Stouraitis, Ioannis (2014), 'Roman identity in Byzantium: A critical approach', in: Byzantinische Zeitschrift 107, 1, 175-220.

Tapkova-Zaimova, Vasilka (1984), 'Les 'Romains' dans la culture slave: la littérature bulgare médiévale', in: La nozione di “Romano" tra cittadinanza e universalità, Da Roma alla terza Roma, Documenti e Studi. Studi-II, 21 Aprile 1982, Napoli, 449-460.

Vryonis, Speros (1978), 'Recent Scholarship on Continuity and Discontinuity of Culture: Classical Greeks, Byzantines, Modern Greeks', in: Speros Vryonis (ed.), The "Past" in Medieval and Modern Greek Culture, Malibu, 237-256.

Vryonis, Speros (1999), 'Greek Identity in the Middle Ages', in: Études Balkaniques 6: Byzance et l'hellénisme: L'identité grecque au Moyen-Âge. Actes du Congrès International tenu à Trieste du ler au 3 Octobre 1997, 21-36.

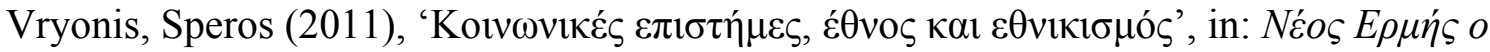

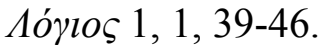

Wimmer, Andreas (2008), 'The Making and Unmaking of Ethnic Boundaries: A Multilevel Process Theory', in: American Journal of Sociology 113, 4, 970-1022. 
